着は $\mathrm{ZnS}-\mathrm{K} \cdot \mathrm{D} \cdot \mathrm{X}$ 系の表面化合物の上に $(\mathrm{D} \cdot \mathrm{X})_{2}$ がバ ルク層をなして吸着するにもかかわらず3)，酸化を受活 た $\mathrm{ZnS}$ に対しては $\mathrm{Zn}(\mathrm{D} \cdot \mathrm{X})_{2}$ が生成し，(D・X $)_{2}$ がバ ルク層をなして吸着する。また酸化試料によつては，ピ リジン冼浄後 $\mathrm{D} \cdot \mathrm{OH}$ が得られるような吸着も存在する。 これらのことは酸化を受けた $\mathrm{ZnS}$ に・D・X を吸着さ せた場合と比較して，(D・X ) 、のバルク層が存在しない
ことの他，同じょうな挙動であることが考えられる。

\section{文献}

1）山崎太郎・日井進之助：昭和 38 年日本釷業会春季大会講演。

2) K. L. Sutherland and I. W. Wark: Principles of Flotation (1955) $211-236$ (Chapter XII)

3) 佐々木弘・ 日井進之助・山崎太郎 : 昭和 39 年日本鉣丵会秋季大会 講演。

\title{
2310 産地の異なる数種の黄鉄鉱に対する銅イオンの活性効果
}

\section{1. まえがき}

黄鉄鉱が銅イオンにより活性化されることは，すで に1)柵原産の黄鉄鉣について明らかにしたところである が，同心゙黄鉄鉱でもその鈗体の生成条件，賦存環境など により鉱物表面の物理化学的性質にある程度の差異が考 えられる。すでにこのため，産状の異なる黄鉄鉱の間で 浮遊性ないしは捕収剤の吸着性などに差異が認められる ことが近年指摘されている。同じょうに銅イオンによる 黄鉄鉱の活性化についても, 産状の相違が活性化の程度 に少なからず影響を拈よぼすことが考えられ，この点を 明らかにすることは理論上なた操業上の見地から有意義 なことであると思われる。

このような観点から本研究では, 㒳原, 花岡 ( 2 種類), 松尾, 豊羽, 尾去沢の各鉱山産出の 6 種類の黄鉄鉱を対 象に同じ条件のもとに浮選実験を行ない，銅イオンによ る活性効果の差異を相互に比較検討したので，その結果 について報告する。

\section{2. 実 験 方 法}

\section{$2 \cdot 1$ 試 料}

上記 6 種の黄鉄鉱の 3 ち花岡鉱のみは硫化鉄鉱体（以 下花岡硫化鉱という） と黄鉱鉱体(以下花岡黄鉱という） の中からえられた 2 種類の黄鉄鉱を用いた。

送付塊鉱は砕いて純粋粒を手選し，さらに20〜48mesh に整粒してウイルフレイテーブルにか将精選し, 乾燥し て保存試料とし，一連の浮選実験の直前に磁製乳ばちを 用いて粉化し 150 200mesh 粒度のものを実験試料とし て使用した。試料の分析值を第 1 表に示す。松尾鉱を除 き，いずれるきわめて純度の高いことがわかる。また銅 の含有量は花岡黄鉱を除きいずれも微量で以下の実験に ゆゆしい影響を与える量とは思われないが，この点花岡 黄鉱のみは留意すべきものと考兄られる

第1表陚料の化学分析 (\%)

\begin{tabular}{|c|c|c|c|c|c|}
\hline 産 地 別 & $\mathrm{Fe}$ & $\mathrm{S}$ & $\mathrm{SiO}_{2}$ & $\mathrm{Cu}$ & Tot. \\
\hline & 46.45 & 51.10 & 0.39 & $<0.05$ & 97.99 \\
\hline 花岡硫化全能 & 45.29 & 51.51 & 2.20 & 0.15 & 99.15 \\
\hline & 42.90 & 48.17 & 4.20 & $<0.05$ & 95.32 \\
\hline 尾 去 沢 & 45.39 & 51.02 & 1.08 & $<0.05$ & 97.54 \\
\hline 松尾 & 27.69 & 29.76 & 35.20 & $<0.05$ & 92.70 \\
\hline 花凮黄鉣 & 42.32 & 49.02 & 2.02 & 3.44 & 96.80 \\
\hline
\end{tabular}

\section{$2 \cdot 2$ 操 作}

上記 $150 \sim 200 \mathrm{mesh}$ 黄鉄鉱試料 $5 \mathrm{~g}$ に対し液全量 $50 \mathrm{cc}$ としガラス製小型浮選セル2)で浮選した。銅イオンには 硫酸銅を, 捕収剤にはエチルキサントゲン酸カリウム

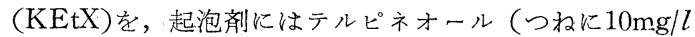
の一定濃度）を, また $\mathrm{pH}$ の調節には水酸化カルシウム

秋田大学鉱山学部助教授真宮 三 男(正会員)

をそれぞれ使用した。

\section{3. 実験結果および考察}

\section{$3 \cdot 1$ 銅イオンの添加効果}
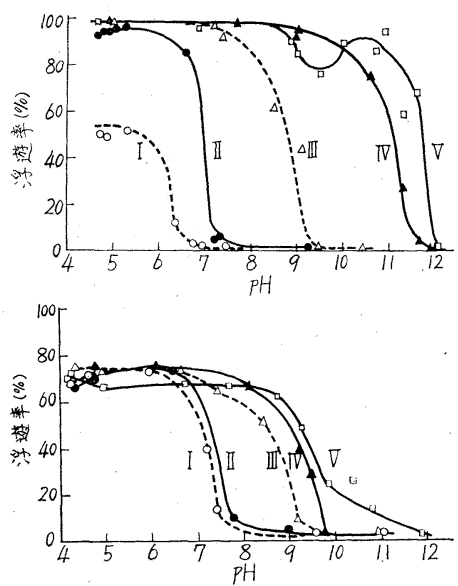

第 2 园 松尾鈜に対する 銅イカンの添加効果 ( $\mathrm{I} \sim \mathrm{V}$ 第 1 図と同し)

I. $\mathrm{KEtX} 5 \mathrm{mg} / l, \mathrm{Cu}^{2+}$ を含まず

II. $\mathrm{KEtX} 5 \mathrm{mg} / l, \mathrm{Cu}^{2+}$ $5.1 \mathrm{mg} / l$

III. $\mathrm{KEtX} 20 \mathrm{mg} / l, \mathrm{Cu}^{2+}$ を含まず

IV. $\mathrm{KEtX} 20 \mathrm{mg} / l, \mathrm{Cu}^{2+}$ $5.1 \mathrm{mg} / l$

V. KEtX $20 \mathrm{mg} / l, \mathrm{Cu}^{2+}$ $25.5 \mathrm{mg} / l$

第 1 図 花岡硫化鉱汇対 す文銅イオンの添加効果
I. 松尾 II. 棚原 III. 花岡 IV. 豊羽 V. 尾去沢 第 3 図各地産出の黄鉄 鉱の浮遊性の比較 (KEtX $5 \mathrm{mg} / \mathrm{l}$ )

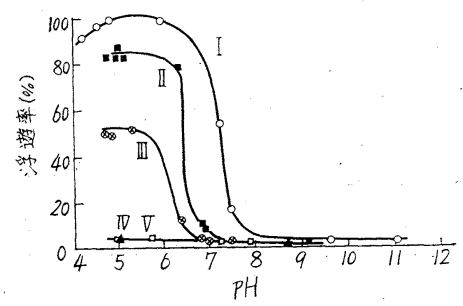

I. $\mathrm{Cu}^{2+を}$ を添加せず iI. 松尾 III. 柵原 IV. 花岡

第 4 図 銅イオンの活性 効果の比較 (松尾, 棚 原, 花峝)

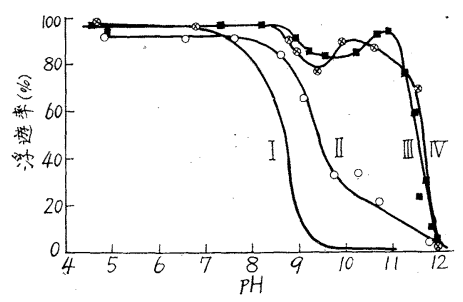

I、 $\mathrm{Cu}^{2+}$ を含まず, 尾法沢 II. $\mathrm{Cu}^{2+}$ 等含 まず, 豊羽 III. 尾去沢 IV. 豊羽 第 5 図 銅イオンの活性 効果の比較 (豊羽, 尾 去沢） 
花岡硫化鉱についてKEt Xの濃度を $5 \mathrm{mg} / l$ とし，浮 遊率と $\mathrm{pH}$ との関係を求めたものを第 1 园曲線 $\mathrm{I}$ に，ま たこの条件でさらに $\mathrm{Cu}^{2}+5.1 \mathrm{mg} / l$ を含む場合を曲線 II に, さらに KEtX の濃度を $20 \mathrm{mg} / l$ とし(曲線 III), こ れに $\mathrm{Cu}^{2}+5.1 \mathrm{mg} / l$ および $25.5 \mathrm{mg} / l$ を含む場合をそれ

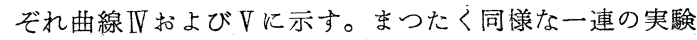
を他の 5 種類の黄鉄鉱についても行なつたが, その一例 として第 2 図に松尾鉣についての結果を揭げた。

黄鉄鉱は一般に中性ないし酸性側で良く浮遊し, 塩基 性が強くなるにしたがつて抑制されるので,浮遊率と $\mathrm{pH}$ との間に明瞭な臨界曲線がえられる。捕収剤の増量に伴 なつてこの曲線がより塩基性側に移動することは周知の と拈りであるが，図に見られるように銅イオンを加えて む同じような現象が扔こる。したがつて銅イオンを含ま ない時々比較して曲線の偏移の程度から銅イオンによる 活性効果の程度が判定できる。

これら一連の実験から 6 種類の試料の間に, 程度の差 こそあるけれども総じて銅イオンの添加によつて顕著な 活性効果が認められることがわかつた。

\section{$3 \cdot 2$ 浮遊性の比較}

花岡黄鉱を除く他の 5 種の試料について相互の浮遊性 を比較するため, 上述の結果から $\mathrm{KEtX}$ の濃度 $5 \mathrm{mg} / \mathrm{l}$ の場合の浮遊率と $\mathrm{pH}$ との関係を一括, 対比して示すと 第 3 図のようになる。松尾鈗のみは試料中に $25 \%$ 程度の
遊離の脈石粒を含むことを確認したので，他の試料との 対比上脈石粒が当該黄鉄鉣の浮遊性になんの影響も扣よ 注さないものと仮定して75\%浮遊率を 100\%浮遊率に换 算して書き变えた。図からわかるようにこの条件下では 松尾, 柵原, 花岡の順に良く浮遊し, 豊羽, 尾去沢の試 料はともに浮遊性が悪い。

\section{$3 \cdot 3$ 活性効果の比較}

各試料について銅イオンによる活性效果の程度を相互 に比較するため，前の結果から一例として KEtX の濃 度を $20 \mathrm{mg} / l$ とし $\mathrm{Cu}^{2}+25.5 \mathrm{mg} / l$ の濃度の場合について 浮遊率と $\mathrm{pH}$ との関係を対比して示寸と第 4 図, 第 5 図 のようになる。第 4 図の曲線は銅イオンを含まない $\mathrm{KEtX} 20 \mathrm{mg} / l$ のときの臨界 $\mathrm{pH}$ 曲線で, 松尾, 柵原, 花岡硫化鉱の 3 試料ともほとんど一致しているので曲線 Iを基準に 3 試料を一括して対比した。

第 4 図，第 5 図からわかるよ5に銅イオンの活性効果 は花岡硫化鉱，柵原鉱の順にともに顕著であるが，これ に比し松尾鉱では効果の程度がかなり僅少である。また 活性効果は豊羽鉱に顕著におこるが，尾去沢鈗では比較 的弱い。

$$
\text { 文 献 }
$$

1）横山，真宮：日本釷業会誌，72，61（1956）

2）横山，真宮：日本鉱業会誌，74，480（1958）

\section{1 黒鉱の $\mathrm{SO}_{2}$ 浮選における銅鉱物の浮選速度特性について}

$\begin{array}{rrrrr}\text { 東京大学工学部教授・工博 } & \text { 今 } & \text { 泉 } & \text { 常 } & \text { 正(正会員) } \\ \text { 同和欸業(株)企画部, 東京大学受纴研究員 } & \bigcirc \text { 青 } & \text { 木 } & \text { 勝 } & \text { 男(正会員) }\end{array}$

\section{1. 緒 言}

黒鉱のような複雑硫化鉱の浮選を行なう場合，前もつ て各成分鉱物の浮選特性を把握しておくことがとくに重 要である。筆者らは黒鉱浮選の研究の一端として $\mathrm{SO}_{2}$ 水 を添加した条件下に打ける各種銅鉱物の浮選挙動を考察 するため，小坂鉱山内の岱鉱につき回分式ならびに現場 試験を行なつた。浮選特性の解析にあたつては, 速度論 的手法を応用し，化学分析および検鏡分析の結果にもと づいて, $\mathrm{SO}_{2}$ 浮選に拈ける各成分鉣物の浮選速度特性を 定量的に把握し，さらに鉣物粒子の粒度々優先分離度の 関係，その他について 2,3 の考察を行なつた。

\section{2. 試 験 方 法}

試験は実験室に打ける回分式試験と現場に打ける連続 浮进時间 (min)

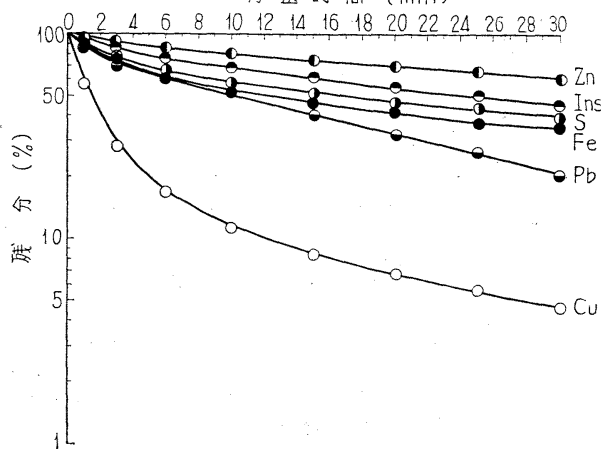

第 1 図 回分式浮選試験結果 (1) 一成分別浮選速度曲線

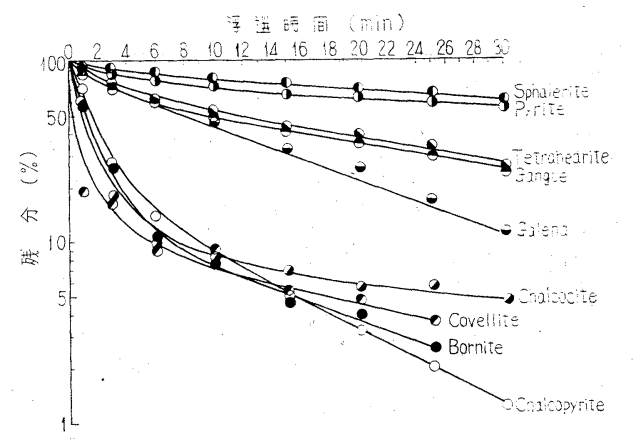

第 2 図 回分式浮選試験結果 (2)一構成鉣物別浮選速度曲線 粒度 $53 / 37 \mu$

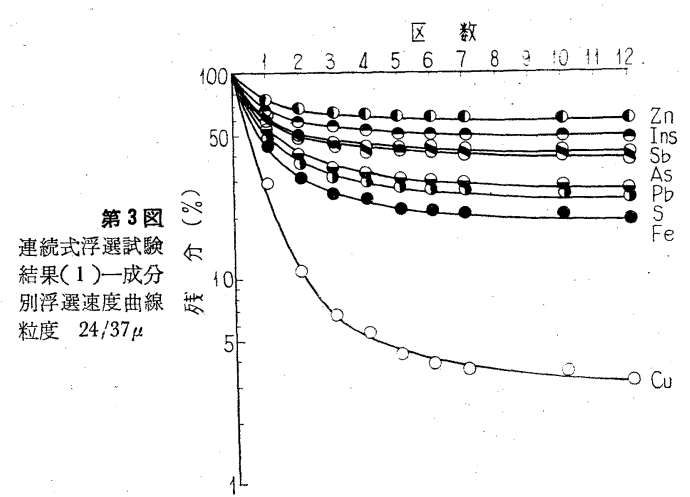

